\title{
POLA KOMUNIKASI DAN NORMA PENGGUNAAN INTERNET PADA ORANG TUA TERHADAP KECANDUAN ANAK DALAM PENGGUNAAN YOUTUBE di ERA DIGITAL
}

\author{
Henny Agustiningrum ${ }^{1}$, Martani Huseini ${ }^{2}$ Kinkin Yuliaty Putri Subarsa ${ }^{3}$ \\ ${ }^{1}$ STIKOM InterStudi, hennyagusti@ @tikom.interstudi.edu \\ ${ }^{2}$ Universitas Indonesia, martani0703@yahoo.com \\ ${ }^{3}$ Universitas Negeri Jakarta, kinkinsubarsa@unj.ac.id
}

\begin{abstract}
ABSTRAK
Penelitian ini memprioritaskan peran orang tua dalam menerapkan pola komunikasi termasuk konsistensi norma ketika orang tua menggunakan internet dan bagaimana orang tua memahami serta menyadari bahwa saat ini banyak anak yang mengalami kecanduan ketika menggunakan YouTube. Fakta ini diharapkan dapat menjadi masukkan bagi para orang tua diera digital ini untuk tidak hanya menerapkan aturan namun juga dapat memberikan contoh yang baik kepada anak-anaknya. Penelitian ini memiliki tujuan untuk mengukur pengaruh antara pola komunikasi dan norma penggunaan internet pada orang tua terhadap kecanduan anak dalam penggunaan YouTube di era digital. Kriteria responden dalam penelitian ini adalah anak-anak yang duduk di bangku Sekolah Dasar (SD) dengan tingkatan kelas mulai dari kelas 3-6 dimana mereka diminta untuk mengisi kuesioner secara anonim melalui kuesioner online yang mencakup semua faktor yang disebutkan. Hasil penelitian mengungkapkan bahwa pola komunikasi dan norma penggunaan internet pada orang tua memiliki pengaruh secara simultan terhadap kecanduan anak dalam penggunaan YouTube. Penelitian sebelumnya banyak membahas tentang kecanduan internet di kalangan remaja. Namun, mengingat saat ini merupakan era serba digital dimana kecanduan menggunakan YouTube lebih banyak mengarah pada anak usia sekolah dasar maka hal inilah dirasa perlu dilakukan penelitian mendalam.
\end{abstract}

Kata Kunci : pola komunikasi, norma penggunaan internet, kecanduan YouTube

\begin{abstract}
This study prioritizes the role of parents in applying communication pattern, including the consistency of norms when parents use the internet, and how parents understand and realize that currently many children are addicted to YouTube. This fact is intended to inspire parents not only to abide by the rules, but also to be a good example for their kids in this digital era. This study aims to quantify the influence between parental communication patterns and internet usage norms and their children addiction to YouTube's use in the digital age. The respondents criteria in this study were children in elementary school (SD), grade levels ranging from 3 to 6 , where they were asked to fill out a questionnaire anonymously through an online questionnaire that included all the factors mentioned. The results revealed that parental communication patterns and internet usage norms had a simultaneous influence on children's addiction to YouTube use. The previous research has discussed a lot about internet addiction among adolescents. However, considering today we are on a digital era, where addiction using YouTube is found on elementary school-age children, therefore this fact needs to have futher research.,
\end{abstract}

Keywords: communication patterns, internet usage norms, YouTube addiction 


\section{PENDAHULUAN}

Banyaknya penemuan baru perihal kemajuan teknologi yang semakin cepat berkembang membuat teknologi memberikan banyak manfaat dan kemudahan serta memberikan kehidupan yang nyaman dan menyenangkan bagi manusia. Hal ini berbanding terbalik dengan zaman sekarang dimana masyarakat menjadikan internet sebagai media interaktif serta telah memberikan kemudahan bagi para penggunanya (Prasanti, 2016).

Berkaitan dengan berkembangnya teknologi di era digital membuat manusia semakin hari semakin tidak dapat lepas dari perangkat elektronik, sehingga perubahan di era digital inipun menimbulkan dampak positif maupun dampak negatif. Teknologi yang saat ini telah dimiliki untuk semua kalangan adalah gadget.

Gadget tidak lagi dijadikan sebagai alat komunikasi melainkan sebagai sebagai sebuah kebutuhan sehari-hari, contohnya sebagai alat bisnis terkait usaha dan pekerjaan, sebagai petunjuk informasi dan juga sebagai alat hiburan bagi semua kalangan baik balita, anak muda, orangtua maupun manula. Bahkan, tidak jarang gadget sendiri digunakan orang tua sebagai suatu hal yang wajib dengan tujuan pengganti pengasuh anak. Ragam dan jenis fitur maupun aplikasi yang sangat lengkap dan menarik membuat orang tua memiliki tujuan menjadikan gadget dapat mendampingi anak sehingga tidak menganggu aktifitas mereka dan anak tidak akan menangis, memberantakan rumah, serta melakukan aktifitas di luar rumah yang akan mebuat orang tua cemas (Chusna, 2018).

(Pratama, dkk., 2019) mengemukakan bahwa saat ini, dapat kita lihat bahwa anakanak pada usia sekolah dasar pun dengan lihainya dapat mengoperasikan seluruh aplikasi yang ada dalam gadget, baik itu mengambil gambar (foto), mengunduh dan memulai permainan baru (game) atau bahkan melakukan penelurusan berita (berselancar) melalui YouTube, Instagram, Facebook dan media lainnya (Fariza, 2018). Dengan mahirnya anak dalam menggunakan gadget beserta aplikasinya, maka orang tuapun banyak yang merasa bahwa anak-anaknya tanggap atau melek dalam urusan perkembangan teknologi. Banyak juga orang tua yang berkesimpulan dan menganggap bahwa gadget dapat dijadikan sebagai teman bermain yang aman bagi anak karena dapat diawasi secara langsung. Padahal, banyak orang tua yang lengah berkaitan dengan penggunaan gadget pada anak (Fujioka \& Austin, 2002).

Penelitian lain menjelaskan bahwa faktor terpenting dalam setiap tumbuh kembang anak adalah bagaimana orang tua dapat berperan agar anak dapat menyesuaikan dirinya pada keadaan (lingkungan) yang telah berpangkal pada teknologi. Terkait dengan kondisi ini, maka orang tua sangat memiliki peran yang besar dengan tujuan dapat dijadikan sebagai benteng pengingat agar kelak anak dapat memilah mana yang boleh dilakukan serta mana yang tidak boleh dilakukan (Nurlina, 2019). Peran keluarga sangatlah memiliki andil, hal ini disebabkan karena orang tua merupakan lingkup utama yang pertama kali diketahui oleh anak dan mempunyai bagian dalam tumbuh kembangnya, sehingga tidak heran bahwa anak akan menjadikan orang tua sebagai panutan (Setyowati, 2013).

\section{KAJIAN LITERATUR}

\section{a. Pola Komunikasi}

Pola komunikasi yang terjalin dalam sebuah keluarga lebih mengarah pada komunikasi antar pribadi. Komunikasi antar pribadi memiliki pola dan ciri khas tersendiri yang sangat berbeda dengan pola komunikasi lainnya, contohnya komunikasi kelompok, komunikasi organisasi atau bahkan dalam pola komunikasi massa. Komunikasi ini memiliki kekuatan dimana adanya keterbukaan diri yang terjalin antara komunikator dengan komunikan. Ragam lain dalam komunikasi antar pribadi sifatnya lebih spontanitas, penuh keterbukaan, eufisme atau bahkan membuat kata-kata menjadi lebih halus (Sari, dkk., 2010). Dalam sebuah keluarga, komunikasi antar pribadi bisa terjadi dikarenakan anggotanya terdiri dari 2 sampai dengan 3 orang. Komunikasi ini lebih bersifat diadik dan triadik, dimana komunikasi antar pribadi tidak hanya tentang isi dari pesan yang hendak disampaikan melainkan fokusnya lebih pada relasi/hubungan yang terjalin 
karena komunikasi ini bersifat dua arah (Pratikto, 2017).

Pola komunikasi sebenarnya lebih cenderung berfokus pada peran orang tua, bagaimana pesan yang disampaikan oleh orang tua dalam pola komunikasi keluarga juga memengaruhi perilaku dan pandangan anak terhadap dunia. (Chaffee, et al., 1971) menyatakan bahwa pola komunikasi keluarga mempengaruhi persepsi anak terhadap realitas sosial, karena pola komunikasi diadopsi sebagai kerangka kerja untuk menafsirkan lingkungan. Semakin banyaknya teori yang berkembang menunjukkan bahwa beberapa kendala juga berlaku dalam pola komunikasi keluarga yaitu tahapan perkembangan anak secara kognitif. Perkembangan kognitif pada anak melalui serangkaian tahapan pertumbuhan mental. Adapun tahapan menggambarkan struktur mental yang berfungsi sebagai proses pengkodean yang digunakan anak-anak untuk mencerna dan memahami dunia melalui pesan yang mereka terima (Koerner \& Mary Anne, 2002).

Dalam sebuah anggota keluarga, budaya berkomunikasi saat ini adalah hal yang sulit untuk ditemui. Tidak jarang dalam sebuah keluarga ketika orang tua menanyakan kabar anaknya atau bahkan ketika sang Ibu mengajak anaknya untuk makan malam bersama ia memanggilnya melalui perantara teknologi seperti WhatsApp, Yahoo Messanger, Line Chat atau bahkan melalui panggilan telepon langsung. Saat ini, begitu sulit kita melihat sebuah keluarga dapat menikmati kebersamaan suasana berkumpul yang utuh, suasana dimana orang tua dapat mendengarkan cerita anaknya dalam mengisi hari-harinya di kegiatan sekolah, tempat les atau bahkan keluh kesah anak terkait dengan lingkungan di luar rumah, bercengkerama bersama keluarga sambil menikmati acara televisi atau makanan favorit keluarga dimana ini merupakan hal yang langka bahkan nyaris tidak lagi dapat kita temukan dalam sebuah kehidupan keluarga. Ironisnya, yang semakin tampak saat ini adalah dalam setiap anggota keluarga justru lebih tertarik untuk berkomunikasi dengan menggunakan alat komunikasi dengan teknologi yang lebih bersifat individualisme atau bahkan cenderung merambah dunia maya. Hal inilah yang merupakan salah satu kemajuan yang pesat di bidang teknologi komunikasi (Pratikto, 2017).

Perkembangan teknologi di era digital dewasa ini telah menenggelamkan tentang makna sesungguhnya dari arti pola komunikasi dalam sebuah keluarga. Semua informasi dan komunikasi yang bersifat cepat dan instan telah diambil perannya oleh sebuah interaksi dari media sosial. Dalam menjalankan proses komunikasi penerapan setiap keluarga selalu berbeda-beda. Keberadaan orang tua dalam sebuah keluarga merupakan sebagai pembimbing karena bertanggung jawab penuh akan pembentukan karakter, sikap dan perilaku anak. Orang tua mempunyai kewajiban untuk mengontrol dan mengawasi setiap informasi yang diterima oleh anak serta memberikan pengertian dan penjelasan yang tepat agar anak dapat mencerna dan memahaminya (Lestari, dkk., 2015).

Alhasil, komunikasi yang dihasilkan pada keluarga di era digital cenderung bersifat individualisme dimana tercipta sebuah kehidupan yang sunyi namun di tengah keramaian. Banyak orang tua yang sudah tidak lagi memiliki waktu untuk berkomunikasi secara intens dan mendengarkan keluh kesah anaknya atau bahkan mendampingi anak pada saat belajar. Anak cenderung mengisi kekosongan dan membunuh rasa kesepiannya dengan melakukan aktifitas selancar seperti curhat dengan membuat status WhatsApp, Instagram, Facebook atau bahkan memuaskan kesenangan dengan mendapatkan informasi terbaru melalui konten YouTube, bermain game online serta melihat fitur belanja melalui online (Setiawan, 2017).

\section{b. Norma Penggunaan Internet Pada Orangtua}

Orang tua merupakan role model bagi anak-anaknya. Semua perilaku dan sikapnya tentu saja akan menjadi contoh nyata bagi anak. Hal keseharian orang tua yang dapat ditiru anak adalah cara bersikap dan bertutur kata. Perilaku orang tua lainnya yang dapat ditiru anak adalah aktifitas keseharian yang mereka lakukan seperti merokok, penyalahgunaan narkoba ataupun mengkonsumsi minuman beralkohol (Tilson, et al., 2004). 
Dalam penelitian (Bandura, 1989) juga disebutkan bahwa banyak perilaku orang tua yang secara tidak sadar diamati oleh anak. Mereka dengan spontan mengingat, meniru atau bahkan mencamkan seluruh kalimat atau perkataan orang tua pada anaknya seperti kalimat berjanji, bersumpah atau bahkan aktifitas keseharian orang tua yang dengan mudah akan direkam oleh anak.

Kualitas hubungan orangtua dan anak yang tidak terjalin harmonis juga dapat dikaitkan dengan tingkat kecanduan internet. Dalam proses belajar ataupun meniru perilaku orang tua, seorang anak pastinya akan sulit untuk mencerna tentang sikap dan norma orang tua yang tidak menerapkan konsistensi pola didik. Pengaruh norma dan perilaku orang tua mengenai penggunaan internet dan komunikasi dengan anak yang memiliki Pathological Internet Use (PIU) dapat dilihat dalam dua kondisi, yaitu perilaku penggunaan internet orang tua itu apakah konsisten dengan norma (aturan) tentang penggunaan internet dan juga tentang perilaku orang tua yang tidak konsisten dengan norma tersebut (Bandura, 2012).

Orang tua biasanya memperlihatkan sikap dan menerapkan aturan yang bersifat injunctive (persepsi tentang perilaku mana yang perlu diterima maupun yang tidak perlu diterima) terhadap pandangan orang tua tentang dampak penggunaan internet yang berlebihan pada anak, hal inilah yang disebut dengan norma. Beberapa penelitian juga telah difokuskan tentang norma khusus orang tua dalam menggunakan internet. Beberapa kasus juga ditemukan bahwa aturan orang tua tentang batasan penggunaan internet dapat membantu PIU pada anak (Peeters et al., 2018).

Menurut penelitian tentang norma penggunaan internet pada orang tua juga masih dikaitkan dengan bagaimana pola komunikasi yang mereka terapkan pada interaksi antara orang tua dengan anak terjalin dengan baik. Ketika orang tua berkomunikasi dengan anak maka sebaiknya menempatkan dimensi yang relatif independen, diantaranya:

(a) menekankan nilai ide-ide menantang tanpa banyak perhatian pada kontroversi dan (b) menekankan rasa hormat dan harmoni serta menghindari kontroversi (Chaffee et al., 1971). Penelitian sebelumnya mengeksplorasi bagaimana norma penggunaan Internet pada orang tua dikaitkan dengan pola komunikasi orang tua pada anak yang cenderung memperkuat pesan tentang bagaimana penggunaan Internet yang diketahui sebagai media yang dapat menimbulkan hal positif maupun negatif (Fujioka \& Austin, 2002).

\section{c. Kecanduan Anak Dalam Penggunaan YouTube atau Pathological Internet Use (PIU)}

Griffiths and Hunt dalam penelitian (Leung \& Lee, 2012) menjelaskan tentang konsep 'kecanduan' yaitu sesuatu yang berkaitan dengan hal-hal medis dan dikaitkan dengan ketergantungan baik fisik maupun psikologis tetapi bukan pada pola perilaku. Selain itu dalam penelitan lainnya disimpulkan bahwa kecanduan diperluas untuk mencakup perilaku kecanduan. Konsep kecanduan teknologi sebenarnya dapat di definisikan sebagai interaksi yang terjadi antara manusia dengan mesin dan sifatnya lebih mengarah pada non-kimia. Terlepas dari itu semua, sebenarnya masih menjadi perdebatan tentang apakah jika teknologi digunakan secara berlebihan, seperti berselancar di internet, menonton televisi, dan bermain komputer dalam durasi yang cukup lama, dapat atau harus disebut sebagai 'kecanduan', namun para ahli berpendapat bahwa penggunaan teknologi yang berlebihan memang dapat dianggap sebagai kategori "bermasalah".

Ketika anak telah memasuki fase "kecanduan", maka orang tua merupakan sosok ataupun figur yang sangat penting dan berpengaruh dalam mendidik, mengasuh anak serta mencegah permasalahan terkait dengan penggunaan internet yang berlebih. Beberapa penelitian juga telah dilakukan berkaitan dengan karakteristik sebuah keluarga dan dampak dari kecanduan internet. Hasilnya terlihat dari kualitas hubungan orangtua dan anak yang tidak harmonis serta fungsi 
keluarga seutuhnya yang dikaitkan dengan tingkat kecanduan internet (Van Den Eijnden, et al., 2010).

Masih banyak orang tua yang tidak menyadari dan menganggap sepele apabila anak kecanduan dalam menggunakan gadget. Orang tua tidak memahami bahwa kecanduan gadget merupakan hal yang berbahaya karena dapat merusak psikis dan fisik anak. Bahkan, banyak orang tua yang tidak menyadari pada saat anak menghabiskan waktu bermain game ataupun menonton YouTube dan Instagram selama 3 jam nonstop tanpa ada jeda maka anak tersebut dapat dikategorikan sebagai kecanduan (Alia \& Irwansyah, 2018).

Hasil dari penelitian lainnya juga menunjukkan bahwa kecanduan internet dapat mengganggu kegiatan akademik, pekerjaan, mempengaruhi kinerja profesional dan kehidupan sosial, melupakan waktu istirahat, mengabaikan tanggung jawab keluarga, dan menjadikan prioritas lebih ketika berselancar di dunia maya. Tidak hanya itu, bukti lain juga menunjukkan bahwa anak yang kecanduan internet akan mengalami gangguan psikologis, mengalami gangguan penyakit mental yang ditandai oleh keinginan yang tidak terkendali untuk melakukan sebuah tindakan (Young, 2013).

Beberapa penelitian lainnya juga telah membuktikan tentang hubungan antara komunikasi dan karakteristik hubungan keluarga dengan anak yang mengalami kecanduan internet. Beberapa penelitian tersebut menggunakan istilah "Pathological Internet Use" (PIU) untuk menggambarkan pola penggunaan Internet yang terganggu. PIU didefinisikan dalam hal penggunaan Internet yang menyebabkan sejumlah gejala tertentu, termasuk penggunaan Internet yang mengubah suasana hati, kegagalan untuk memenuhi kewajiban peran utama, rasa bersalah, dan keinginan (Davis, 2001).

Kecanduan internet merupakan sebuah hal yang nyata dan terjadi dalam kehidupan sehari-hari. Seperti halnya kecanduan alkohol, kecanduan narkoba, atau perjudian, kecanduan dalam menggunakan internet juga berdampak buruk pada kehidupan pecandu dan keluarga mereka. Dampak dari kecanduan ini seperti contohnya terjadinya perceraian, kehilangan pekerjaan, turunnya produktivitas di tempat kerja, kegagalan di sekolah, dan dalam kasus-kasus ekstrem, mengarah pada perilaku kriminal. Definisi lain dari Pathological Internet Use (PIU) ini mengharuskan individu memenuhi lima dari delapan kriteria kecanduan internet agar dapat memenuhi syarat dan termasuk sebagai pecandu. Kriteria ini meliputi (1) keasyikan dengan internet, (2) membutuhkan waktu online yang lebih lama, (3) upaya berulang untuk mengurangi penggunaan internet, (4) penarikan ketika mengurangi penggunaan internet, (5) masalah manajemen waktu, (6) tekanan lingkungan (keluarga, sekolah, pekerjaan, teman-teman), (7) ketidak jujuran tentang waktu yang dihabiskan ketika online, dan (8) modifikasi mood melalui penggunaan internet (Young, 2017).

Dalam penelitian lain juga disebutkan bahwa seorang anak yang kecanduan internet berawal dari minimnya komunikasi yang tercipta dengan baik dalam keluarga. Beberapa penelitian juga menyarankan bahwa komunikasi orang tua dengan anak dapat menjadi menjadi pelindung dari faktor PIU. Perilaku berisiko lainnya berhubungan dengan anak yang kecanduan internet secara bersamaan menarik perhatian orang tua untuk lebih waspada, karena banyak orang tua khawatir jika kecanduan internet dapat menyebabkan hal yaitu anak-anak menjadi terisolasi dari orang lain, membuat anak lebih tertarik pada gambar-gambar seksual atau kekerasan, menanggalkan kegiatan yang lebih bermanfaat dan lebih menutup diri berkaitan dengan privasi mereka (Kim \& Kim, 2015).

Gambar 1 Kerangka Konsep Penelitian 


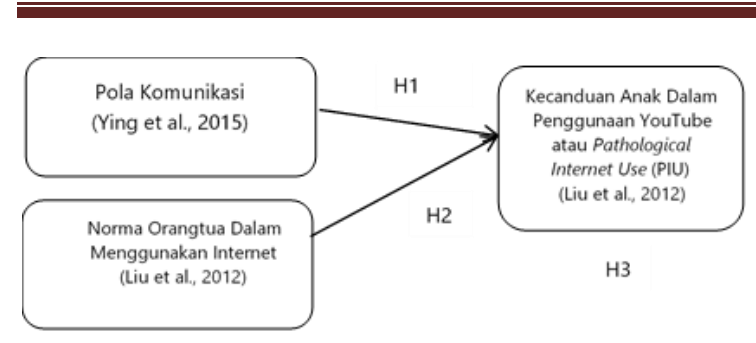

Berdasarkan kerangka konsep penelitian di atas, penelitian ini membahas 2 (dua) variabel dan 3 (tiha) hipotesis. Adapun variabel yang diuji yaitu 1) Pola Komunikasi, 2) Norma orangtua Dalam Menggunakan Internet, serta 3) Kecanduan Anak Dalam Penggunaan YouTube (PIU). Adapun hasil hipotesisnya adalah sebagai berikut:

H1 : Adanya pengaruh Pola Komunikasi (X1) terhadap Kecanduan Anak dalam Penggunaan YouTube (Y)

H2 : Adanya pengaruh Norma Penggunaan Internet pada Orangtua terhadap Kecanduan Anak dalam Penggunaan YouTube (Y)

H3 : Adanya pengaruh Pola Komunikasi (X1) dan Norma Penggunaan Internet pada Orangtua (X2) secara simultan terhadap Kecanduan Anak dalam Penggunaan YouTube (Y)

\section{Metode Penelitian}

Penelitian ini menggunakan kuantitatif. Analisis statistik dilakukan secara sistematis. Pertama, menghitung rata-rata setiap skala untuk dianalisis mulai dari pola komunikasi orang tua dengan anak, norma penggunaan internet pada orang tua sampai pada PIU. Setelah mengkorelasikan skor semuanya beberapa regresi dilakukan untuk melihat kaitan antara gender anak, tingkat kelas, pendapatan keluarga dan tingkat pendidikan orang tua. Setelah faktor terkontrol dimasukkan ke dalam model regresi dalam langkah pertama pola komunikasi orang tua dengan anak, norma penggunaan internet pada orang tua dimasukkan pada langkah ke dua, ketergantungan penggunaan internet pada anak dimasukkan pada langkah terakhir. Jumlah responden yang diambil adalah 100 siswa yang dipilih dari tingkat Sekolah Dasar (SD) mulai dari kelas $3-6$. Anak laki-laki dan anak perempuan dilibatkan dalam penelitian ini. Kisaran usia anak dimulai dari usia 8 - 12 tahun. Alasannya dimulai dari usia
8 tahun adalah karena usia ini dianggap dapat memahami pernyataan atau pertanyaan yang diberikan pada kuesioner.

Saat pengisian kuesioner telah memasuki tahap awal pandemic COVID 19, maka prosedur langkah awal yang dilakukan dalam mengisi kuesioner setelah diinformasikan dan mendapatkan persetujuan yang telah diperoleh dari sekolah dan tentunya pihak guru berkoordinasi dengan meminta izin pada orang tua melalui group kelas orang tua. Langkah kedua adalah siswa diundang untuk bergabung dalam meeting zoom yang disebarkan melalui group kelas dengan dibantu oleh wali kelasnya masing-masing dan memberikan penjelasan secara intens perihal pengisian kuesioner agar mereka paham betul dan menghindari kesalahan. Kuesioner diisi secara anonim. Informasi lisan perihal kuesioner ini juga disampaikan kepada para siswa dimana mereka dengan bebas dapat menolak untuk diikutsertakan dalam penelitian ini. Siswa akan dijelaskan dan nantinya akan ditekankan kepada semua tentang keaslian data, kemandirian dalam mengisi kuesioner dan sifat integral dari semua jawaban serta kerahasiaan informasi yang dikumpulkan. Siswa akan diminta untuk mencantumkan demografi mereka (misalnya usia, jenis kelamin, dan tingkat kelas), status ekonomi keluarga, PIU, komunikasi antara orangtua dengan anak yang dirasakan, perilaku dan norma penggunaan Internet oleh orang tua terkait penggunaan Internet seharihari.

Tabel 1. Operasionalisasi Variabel

\begin{tabular}{|c|c|}
\hline Variabel & Dimensi \\
\hline \multirow{3}{*}{$\begin{array}{l}\text { Pola Komunikasi } \\
\text { (Ying et al., 2015) }\end{array}$} & $\begin{array}{l}\text { Komunikasi Orangtua } \\
\text { Dengan Anak }\end{array}$ \\
\hline & $\begin{array}{l}\text { Keterbukaan Dalam } \\
\text { Berkomunikasi }\end{array}$ \\
\hline & $\begin{array}{lr}\text { Tingkat } & \text { Masalah } \\
\text { Komunikasi } & \text { Dalam } \\
\text { Keluarga } & \end{array}$ \\
\hline \multirow{2}{*}{$\begin{array}{l}\text { Norma Orangtua } \\
\text { Dalam } \\
\text { Menggunakan } \\
\text { Internet } \\
\text { (Liu et al., 2012) }\end{array}$} & $\begin{array}{l}\text { Perilaku penggunaan } \\
\text { internet pada orang tua }\end{array}$ \\
\hline & $\begin{array}{lr}\text { Norma } & \text { Orangtua } \\
\text { Dalam } & \text { Penggunaan } \\
\text { Internet } & \\
\end{array}$ \\
\hline
\end{tabular}




\begin{tabular}{lll}
\hline & \multicolumn{2}{l}{ Arti Penting } \\
\cline { 2 - 2 } Kecanduan Anak & Toleransi \\
\cline { 2 - 2 } $\begin{array}{l}\text { Dalam Penggunaan } \\
\text { YouTube atau }\end{array}$ & Efek Samping Dari \\
$\begin{array}{l}\text { Pathological } \\
\text { Internet Use (PIU) } \\
\text { (Liu et al., 2012) }\end{array}$ & Kenyahan \\
\cline { 2 - 2 } & Perubahan Sosian Suasana \\
\cline { 2 - 2 } & Hasil Negatif \\
\hline
\end{tabular}

\section{a. Pola Komunikasi}

Skala ini digunakan untuk menilai pola komunikasi antara orang tua dan anak serta antara anak dengan orang tua mereka. Skala ini berisi 20 item dengan menggunakan skala likert dan terdiri dari dua dimensi yang mengukur tingkat keterbukaan dan tingkat masalah dalam komunikasi keluarga. Tanggapan ini dinilai pada skala lima poin yaitu $(1=$ tidak pernah sampai $5=$ selalu $)$ dan dibuat secara terpisah untuk ayah maupun ibu. Skor antara ayah dan ibu digunakan untuk mewakili tingkat rata-rata persepsi komunikasi antara orang tua dan anak dalam penelitian ini (Ying et al., 2015). Nilai alpha cronbach's alat ukur ini 0.864 dengan nilai corrected item-total correlation 0.110-0.713.

\section{b. Norma Orangtua Dalam Menggunakan Internet}

Instrumen ini menilai tingkat yang dirasakan anak ketika orang tua melakukan kegiatan Internet, termasuk informasi penelusuran dan berita, bermain game online, chatting, belanja online dan hiburan (menonton film atau menikmati musik). Ini berisi 5 item yang diukur menggunakan skala lima poin $(1=$ sepenuhnya setuju untuk $5=$ sama sekali tidak setuju) (Liu et al., 2012).

Selain itu berdasarkan pernyataan yang digunakan, kuesioner dikembangkan untuk mengukur penggunaan internet pada orang tua. Kuesioner ini mencakup 5 item untuk 5 aktivitas internet yang dilakukan orang tua, misalnya aktivitas internet: menelusuri informasi dan berita, bermain game online, chatting, belanja online dan hiburan (menonton film atau menikmati musik).
Kuisioner mengukur frekuensi penggunaan internet oleh ayah dan ibu secara terpisah menggunakan lima poin skala $(1=$ tidak pernah sampai $5=$ selalu). Nilai rata-rata ayah dan ibu digunakan untuk mewakili tingkat rata-rata orang tua ketika menggunakan internet dalam penelitian ini (Liu et al., 2012). Nilai alpha cronbach's alat ukur ini 0.488 dengan nilai corrected item-total correlation 0.45-0.424.

\section{c. Kecanduan Anak Dalam Penggunaan YouTube atau Pathological Internet Use (PIU)}

Lei dan Yang menggunakan skala Penggunaan PIU berisi 38 item dengan enam pernyataan : arti-penting (saya melupakan semua hal ketika sedang bermain internet), toleransi (saya merasakan lebih banyak menghabiskan waktu bermain internet), efek samping dari ketagihan (saya merasa kesal ketika saya tidak dapat mengakses Internet), perubahan suasana hati (apabila sedang online membuat saya merasa lebih baik, ketika saya merasa tertekan maka saya menghabiskan waktu bermain internet), kenyamanan sosial (saya merasa lebih aman saat berkomunikasi dengan orang lain melalui Internet, saya merasa lebih percaya diri ketika berkomunikasi secara tidak langsung dengan orang lain melalui internet) dan hasil negatif (saya mengalami kesulitan dengan tugas sekolah karena saya telah menghabiskan banyak waktu bermain Internet). Responden diminta untuk menilai sejauh mana setiap item itu benar menurut mereka dengan skala lima poin $(1=$ sangat tidak benar sampai $5=$ sangat benar). Skor tinggi mengindikasikan bahwa anak memiliki keterlibatan PIU yang tinggi (Liu et al., 2012). Nilai alpha cronbach's alat ukur ini 0.888 dengan nilai corrected itemtotal correlation $0.138-0.708$.

\section{Hasil dan Pembahasan}

Dalam mengetahui keabsahan kuesioner, maka digunakan uji validitas. Uji T Parsial dapat dikatakan valid apabila nilai $t_{\text {hitung }}>t_{\text {tabel. }}$. 
Uji yang telah dilakukan menunjukkan semua item pertanyaan Pola Komunikasi (X1) terhadap Kecanduan Anak dalam Penggunaan Internet (Y) terdapat sebanyak 20 item pertanyaan memiliki nilai Sig. 0,002 <0,05 maka, terdapat pengaruh Pola Komunikasi Orangtua pada Anak terhadap Kecanduan Anak dalam Penggunaan Internet.Hasil uji item pertanyaan kuesioner pada variabel Perilaku Penggunaan Internet pada Orangtua (X2) terhadap Kecanduan Anak dalam Penggunaan Internet $(\mathrm{Y})$ terdapat sebanyak 10 item pertanyaan memiliki nilai Sig. 0,000 < 0,05 maka, terdapat Pengaruh Perilaku Penggunaan Internet pada Orangtua terhadap Kecanduan Anak dalam Penggunaan Internet. Sementara pada variabel Kecanduan Anak Dalam Penggunaan YouTube atau Pathological Internet Use (PIU) (Y) terdapat sebanyak 38 item pertanyaan memiliki nilai nilai Sig. $0,000<0,05$ maka, terdapat pengaruh Pola Komunikasi Orangtua pada Anak dan Perilaku Penggunaan Internet pada Orangtua secara simultan terhadap Kecanduan Anak dalam Penggunaan Internet.

Uji reliabilitas digunakan untuk mengetahui konsitensi jawaban responden dari dimensi variabel dengan menggunakan Cronbach's Alpha, maka variabel Pola Komunikasi (X1), Norma Penggunaan Internet pada Orangtua (X2) dan Kecanduan Anak Dalam Penggunaan YouTube (Y) ditunjukkan dalam 1 tabel sebagai berikut:

Tabel 2. Uji Reliabilitas

\begin{tabular}{cll}
\hline Variabel & Cronbach's Alpha & $\begin{array}{l}\text { N of } \\
\text { Items }\end{array}$ \\
\hline $\mathrm{X}_{1}$ & 0.864 & 20 \\
$\mathrm{X}_{2}$ & 0.488 & 10 \\
$\mathrm{Y}$ & 0.888 & 38
\end{tabular}

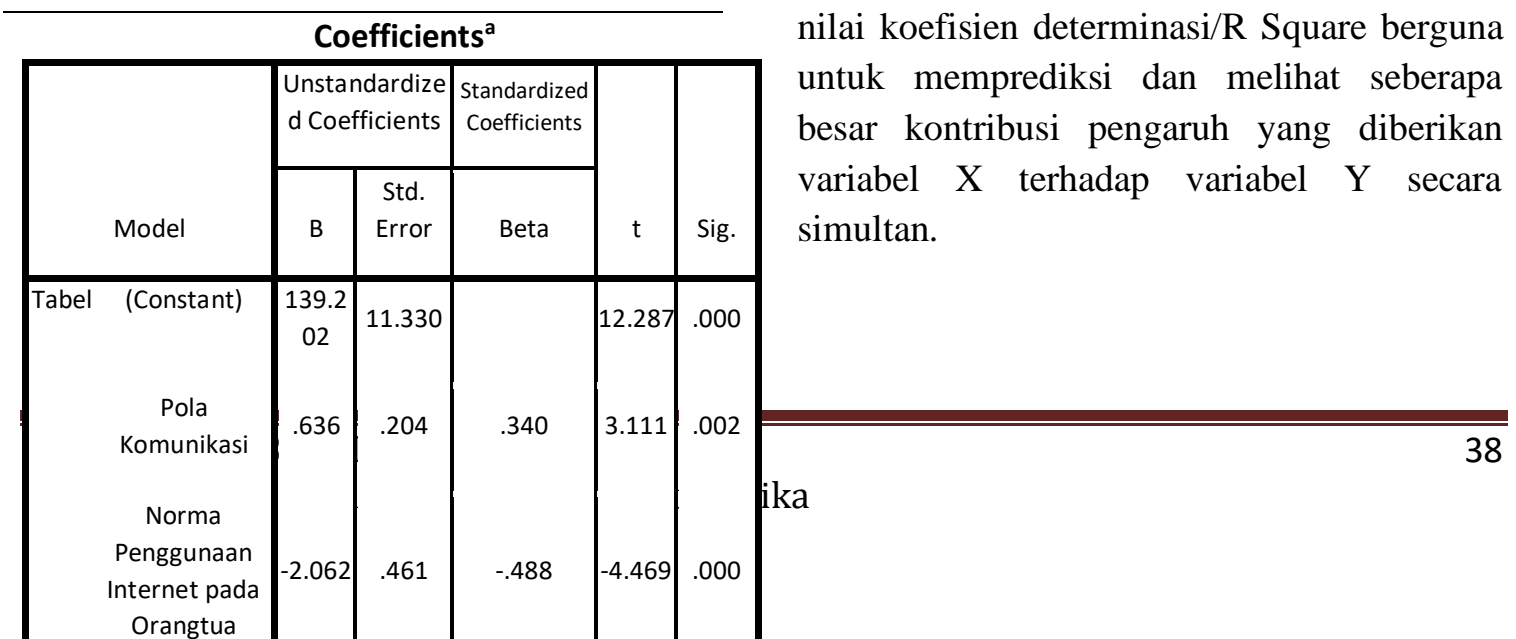

Tabel di atas dapat dijabarkan bahwa nilai Cronbach's Alpha pada variabel Pola Komunikasi (X1) adalah sebesar 0,864 yang dapat diartikan bahwa variabel Pola Komunikasi (X1) sangat reliabel. Sedangkan pada variabel Perilaku Penggunaan Internet pada Orangtua (X2) adalah nilai Cronbach's Alpha sebesar 0.488 dimana dapat diartikan bahwa variabel X2 sangat reliabel. Sementara pada variabel Kecanduan Anak Dalam Penggunaan YouTube (Y) didapat nilai sebesar Cronbach's Alpha 0,888 dimana artinya variabel Y sangat reliabel.

\section{A. Hasil Penelitian}

\section{Uji T}

Tabel 3.

\section{Uji T Menggunakan SPSS}

Berdasarkan tabel tersebut diketahui bahwa pada variabel Komunikasi orang tua dengan anak (X1) di dapatkan nilai signifikansinya 0,002 dengan demikian $<0,05$ sehingga di dapatkan keputusan bahwa terdapat pengaruh yang signifikan dari pola komunikasi orang tua terhadap Kecanduan Anak Dalam Menggunakan YouTube di Era di Digital.

Pada variabel Norma penggunaan internet pada orangtua (X2) di dapatkan nilai signifikansinya senilai 0,000 yang berarti < 0,05. Dapat diambil kesimpulan bahwa terdapat pengaruh yang signifikan dari Norma penggunaan internet pada orangtua terhadap Kecanduan Anak Dalam Menggunakan YouTube di Era di Digital.

\section{Uji Koefisien Determinasi}

Koefisien Determinasi bermakna sebagai sumbangan pengaruh yang diberikan variabel bebas $(\mathrm{X})$ terhadap variabel terikat $(\mathrm{Y})$ atau nilai koefisien determinasi/R Square berguna melihat seberapa variabel $\mathrm{X}$ terhadap variabel $\mathrm{Y}$ secara 
Dalam mengetahui kekuatan sebuah variabel independen maka uji koefisien determinasi (R2) perlu dilakukan. Semakin tinggi nilai koefisien determinan, maka semakin baik model regresi dalam menjelaskan kondisi yang sebenarnya. Hasil yang di dapatkan adalah dalam Tabel sebagai berikut:

Tabel 4. Model Summary

\begin{tabular}{|c|c|c|c|c|}
\hline Model & R & R Square & $\begin{array}{c}\text { Adjusted R } \\
\text { Square }\end{array}$ & $\begin{array}{c}\text { Std. Error of } \\
\text { the Estimate }\end{array}$ \\
\hline 1 & $.419^{\mathrm{a}}$ & .176 & .159 & 18.789 \\
\hline
\end{tabular}

a. Predictors: (Constant), Norma Penggunaan Internet pada Orangtua, Pola Komunikasi Orangtua dengan Anak

Pada tabel di atas, diketahui bahwa nilai Koefisien Determinasi/ R Square adalah sebesar 0,176. Besarnya angka Koefisien Determinasi/R Square adalah 0,176 atau sama dengan 17,6\%. Angka tersebut mengandung makna bahwa variabel Pola Komunikasi Orangtua pada Anak (X1) dan variabel Norma Penggunaan Internet pada Orangtua (X2) secara simultan berpengaruh terhadap Kecanduan Anak dalam Penggunaan YouTube (Y) adalah sebesar 17,6\% sedangkan sisanya $(100 \%-17,65=82,4 \%)$ sebesar $82,4 \%$ dipengaruhi oleh variabel lain diluar variabel yang diteliti. Jika semakin kecil nilai Koefisien Determinasi/R Square, maka berarti pengaruh variabel $\mathrm{X} 1$ dan $\mathrm{X} 2$ terhadap variabel $\mathrm{Y}$ semakin lemah. Sebaliknya jika nilai Koefisien Determinasi/R Square semakin mendekati angka 1, maka pengaruh semakin kuat.

\section{B. Pembahasan Pengaruh Pola \\ Komunikasi (X1) terhadap Kecanduan Anak Dalam Penggunaan YouTube (Y)}

Pola komunikasi orang tua yang diciptakan secara intens pada anak memiliki pengaruh yang kuat dalam membentuk karakter anak. Pola komunikasi yang terjadi di era digital saat ini telah menciptakan sebuah model kehidupan yang mengacu pada kehidupan individualisme dan menjadikan sebuah kehidupan kesepian di tengah keramaian (Ying et al., 2015). Selain itu Ying menambahkan bahwa sesungguhnya pola komunikasi yang terjadi di tengah keluarga merupakan sebuah hal yang harus terus djalin, hal ini bertujuan agar setiap anggota keluarga dapat merasakan sebuah ikatan yang dalam dan yang terpenting adalah merasa saling membutuhkan antara satu dengan yang lainnya.

Pada penelitian ini di dapatkan kesimpulan bahwa variabel Pola Komunikasi (X1) memberikan pengaruh yang positif dan signifikan terhadap Kecanduan Anak dalam Penggunaan YouTube (Y). Hal ini dapat terlihat dari nilai koefisien variabel Pola Komunikasi bertanda positif yang memiliki nilai signifikan $0,002<0,05$. Berdasarkan variabel Pola Komunikasi (X1) dapat diketahui bahwa dimensi "keterbukaan dalam berkomunikasi" memberikan pengaruh yang paling besar dan dimensi "tingkat masalah komunikasi dalam keluarga" memiliki pengaruh paling rendah terhadap Kecanduan Anak Dalam Penggunaan YouTube.

Penelitian lain yang dilakukan oleh (Prasanti, 2016) menunjukkan bahwa perubahan pola komunikasi dalam sebuah keluarga di era digital diciptakan oleh manusianya sendiri. Hal inilah yang pada akhirnya mengakibatkan pola komunikasi antara anggota keluarga baik itu antara orang tua dengan anak ataupun sebaliknya menjadi tidak seimbang dan lancar.

\section{Norma Penggunaan Internet Pada Orangtua (X2) terhadap Kecanduan Anak Dalam Penggunaan YouTube (Y)}

Norma atau perilaku orangtua dalam menggunakan internet sangat mempengaruhi perilaku anak baik secara langsung maupun tidak langsung. Anak akan meniru apa yang dilakukan orangtuanya melalui observasi dan peniruan tindakan serta perilaku orang tua yang mereka lihat sehari-hari, dimana secara 
tidak sadar anak akan merekamnya dan menjadikan itu sebagai contoh yang dapat mereka terapkan juga dalam kesehariannya (Liu et al., 2012). Bahkan dalam penelitiannya Liu menyatakan bahwa anak-anak yang orang tuanya tidak menerapkan norma dalam menggunakan internet dalam arti mereka hanya memberikan aturan kepada sang anak namun tidak konsisten dengan norma tersebut, maka akan berpengaruh pada pembentukan karakter anak menuju kecanduan menggunakan internet atau Pathological Internet Use (PIU).

Pada penelitian ini di dapatkan kesimpulan bahwa variabel Norma Penggunaan Internet Pada Orangtua (X2) memberikan pengaruh yang positif terhadap Kecanduan Anak dalam Penggunaan YouTube (Y). Hal ini dapat terlihat dari nilai koefisien variabel Norma Penggunaan Internet Pada Orangtua (X2) bertanda positif yang memiliki nilai signifikan $0,000<0,05$. Berdasarkan variabel Norma Penggunaan Internet Pada Orangtua (X2) dapat diketahui bahwa dimensi "Ibu aktif menggunakan gadget lebih dari 3 jam setiap hari" memberikan pengaruh yang paling besar dan "Ibu menelusuri informasi berita melalui YouTube memiliki pengaruh yang paling rendah terhadap Kecanduan Anak Dalam Penggunaan YouTube".

Penelitian lain yang dilakukan oleh (Greydanus \& Greydanus, 2012) menunjukkan bahwa norma orang tua dalam penggunaan internet juga berperan penting dalam perilaku anak yang kecanduan internet. Oleh karena itu, pendekatan komunikasi orang tua dalam hal ini keluarga kepada anak secara intens merupakan langkah awal yang harus di jadikan acuan. Orang tua perlu memberikan informasi dan menerapkan norma dan contoh dengan mendidik anak-anak mereka dalam hal perilaku penggunaan internet.

Penelitian lain yang dilakukan oleh (Kalaitzaki \& Birtchnell, 2014) mengatakan bahwa faktor interpersonal yang mempengaruhi kecanduan anak dalam penggunaan YouTube adalah pola komunikasi dalam keluarga serta aturan dan diberikan oleh orang tua perihal penggunaan internet pada anak. Dalam penelitiannya, dijelaskan bahwa ketidak konsistenan orang tua dalam membuat aturan inilah yang membuat anak menjadi tidak memiliki parameter pola asuh. Kalaitzaki juga mengatakan jika menjadi orang tua dari anak-anak yang hidup di era digital saat ini memang tidaklah mudah. Selain menerapkan pola didik tarik ulur maka dibutuhkan juga kesabaran, kecakapan serta kearifan dalam bersikap dan juga dalam bertindak. Hal inilah yang menjadikan peran orang tua sangatlah penting terhadap perkembangan anak-anaknya di zaman sekarang dimana semuanya serba menggunakan teknologi.

\section{PENUTUP}

\section{Kesimpulan}

Dalam hal penerapan aturan dikeluarga, khususnya pengawasan yang sangat efektif pada anak ketika menggunakan gadget merupakan tugas utama dari orang tua. Tidak hanya itu saja, pola komunikasi, perilaku dan norma orang tua dalam menggunakan internet semua harus dipertimbangkan. Pengendalian yang paling penting yang dapat dilakukan orang tua adalah memantau perilaku/sikap dan tindakan mereka sebagai orang tua agar menjadi contoh yang baik bagi anak.

Berdasarkan hasil uji hipotesis menunjukkan bahwa adanya pengaruh pola komunikasi dan norma penggunaan internet pada orangtua secara simultan terhadap kecanduan anak dalam penggunaan YouTube. Responden sendiri akhirnya memahami seluruh pembahasan dari overview question jika menggunakan aplikasi YouTube dan menggunakan gadget lebih dari 3 jam maka dapat dikategorikan sebagai kecanduan.

Hasil studi ini menunjukkan bahwa adanya faktor-faktor lain yang menggaris bawahi tentang hasil penelitian yang tidak terhimpun dari variabel atau skala pengukuran penelitian ini. Adapun beberapa temuan dalam penelitian ini yaitu: 1) Responden dalam penelitian ini adalah anak-anak sehingga dalam teknis pelaksanaan idealnya pengisian kuesioner dibimbing langsung oleh peneliti maka 
kemungkinan ada miss perception terhadap items yang tidak bisa dijelaskan secara langsung, 2) Adanya perbedaan budaya yang dilakukan pada penelitian sebelumnya dimana kuesioner adaptasinya menggunakan bahasa inggris sehingga kemungkinan ada kesalahan persepsi, 3) Pemahaman kalimat yang terbatas dan kurang dipahami oleh responden, 4) Kurangnya keterbukaan responden dalam mengungkapkan fakta keseharian mereka.

\section{Saran}

Berkaitan dengan beberapa permasalahan selama melakukan penelitian ini, maka untuk penelitian selanjutnya dapat dilakukan kepada responden mulai usia tingkat sekolah menengah pertama hingga usia kuliah, Hal ini dikarenakan pembahasan akan lebih meluas dan banyak temuan baru yang dapat dikembangkan.

\section{REFERENSI}

Alia, T., \& Irwansyah. (2018). Pendampingan Orang Tua pada Anak Usia Dini dalam Penggunaan Teknologi Digital. A Journal of Language, Literature, Culture and Education. https://doi.org/10.19166/pji.v14i1.639

Bandura, A. (1989). Regulation of Cognitive Processes Through Perceived SelfEfficacy. Developmental Psychology. https://doi.org/10.1037/00121649.25.5.729

Bandura, A. (2012). Social Foundations of Thought and Action. In The Health Psychology Reader. https://doi.org/10.4135/9781446221129. n6

Chaffee, S. H., Mcleod, J. M., \& Atkin, C. K. (1971). Parental Influences On Adolescent Media Use. American Behavioral Scientist. https://doi.org/10.1177/00027642710140 0304

Chusna, P. A. (2018). Pengaruh Media Gadget Pada Perkembangan Karakter Anak. Dinamika Penelitian: Media Komunikasi Sosial Keagamaan.

Davis, R. A. (2001). Cognitive-behavioral model of pathological Internet use. Computers in Human Behavior. https://doi.org/10.1016/S07475632(00)00041-8

Fariza. (2018). Hubungan Pengetahuan Orang
Tua Tentang Penggunaan Gadget Pada Anak Usia 2-5 Tahun Terhadap Dampak Penggunaan Gadget Di Wilayah Kerja Puskesmas Berseri Pangkalan Kerinci Kabupaten Pelalawan Tahun 2018. Menara Ilmu.

Fujioka, Y., \& Austin, E. W. (2002). The relationship of family communication patterns to parental mediation styles. Communication Research. https://doi.org/10.1177/00936500223783 0

Greydanus, D. E., \& Greydanus, M. M. (2012). Internet use, misuse, and addiction in adolescents: Current issues and challenges. International Journal of Adolescent Medicine and Health. https://doi.org/10.1515/ijamh.2012.041

Kalaitzaki, A. E., \& Birtchnell, J. (2014). The impact of early parenting bonding on young adults' Internet addiction, through the mediation effects of negative relating to others and sadness. Addictive Behaviors.

https://doi.org/10.1016/j.addbeh.2013.12 .002

Koerner, F. A., \& Mary Anne, F. (2002). Understanding Family Communication Patterns and Family Functioning: The Roles of Conversation Orientation and Conformity Orientation. Annals of the International

Communication

Association.

https://doi.org/10.1080/23808985.2002.1 1679010

Lestari, I., Riana, A. W., \& Taftazani, B. M. (2015). Pengaruh Gadget Pada Iinteraksi Sosial Dalam Keluarga. Prosiding Penelitian Dan Pengabdian Kepada Masyarakat.

https://doi.org/10.24198/jppm.v2i2.1328 0

Leung, L., \& Lee, P. S. N. (2012). The influences of information literacy, internet addiction and parenting styles on internet risks. New Media and Society.

https://doi.org/10.1177/14614448114104 06

Liu, Q. X., Fang, X. Y., Deng, L. Y., \& Zhang, J. T. (2012). Parent-adolescent communication, parental Internet use and Internet-specific norms and 
pathological Internet use among Chinese adolescents. Computers in Human Behavior.

https://doi.org/10.1016/j.chb.2012.02.01 0

Nurlina, N. (2019). Peran Orang Tua dalam Pembentukan Kepribadian Anak di Era Digital. AN-NISA https://doi.org/10.30863/annisa.v12i1.45 3

Peeters, M., Koning, I., \& van den Eijnden, R. (2018). Predicting Internet Gaming Disorder symptoms in young adolescents: A one-year follow-up study. Computers in Human Behavior. https://doi.org/10.1016/j.chb.2017.11.00 8

Prasanti, D. (2016). Perubahan Media Komunikasi Dalam Pola Komunikasi Keluarga Di Era Digital. Jurnal Commed.

Pratama, D. Y., Iqbal, I. M., \& Tarigan, N. A. (2019). Makna Televisi Bagi Generasi Z. Inter Komunika: Jurnal Komunikasi. https://doi.org/10.33376/ik.v4i1.292

Pratikto, R. G. (2017). Komunikasi Keluarga Dan Media Baru (Studi Kasus Pergeseran Pola Komunikasi Keluarga pada Masyarakat Urban di Jakarta). InterKomunika. https://doi.org/10.33376/ik.v2i1.14

Sari, A., Hubeis, A., Mangkuprawira, S., \& Saleh, A. (2010). Pengaruh Pola Komunikasi Keluarga Dalam Fungsi Sosialisasi Keluarga Terhadap Perkembangan Anak. Jurnal Komunikasi Pembangunan. https://doi.org/10.29244/jurnalkmp.8.2.

Setiawan, W. (2017). Era Digital dan Tantangannya. Seminar Nasional Pendidikan 2017.

Setyowati, Y. (2013). Pola Komunikasi Keluarga dan Perkembangan Emosi Anak (Studi Kasus Penerapan Pola Komunikasi Keluarga dan Pengaruhnya terhadap Perkembangan Emosi Anak pada Keluarga Jawa). Jurnal Ilmu Komunikasi. https://doi.org/10.24002/jik.v2i1.253

Tilson, E. C., McBride, C. M., Lipkus, I. M., \& Catalano, R. F. (2004). Testing the interaction between parent-child relationship factors and parent smoking to predict youth smoking. Journal of Adolescent Health. https://doi.org/10.1016/j.jadohealth.2003 .09 .014

Van Den Eijnden, R. J. J. M., Spijkerman, R., Vermulst, A. A., Van Rooij, T. J., \& Engels, R. C. M. E. (2010). Compulsive internet use among adolescents: Bidirectional parent-child relationships. Journal of Abnormal Child Psychology. https://doi.org/10.1007/s10802-0099347-8

Ying, L., Ma, F., Huang, H., Guo, X., Chen, C., Xu, F., \& Eapen, V. (2015). Parental monitoring, parent-adolescent communication, and adolescents' trust in their parents in China. PLOS ONE. https://doi.org/10.1371/journal.pone.013 4730

Young, K. S. (2013). Treatment outcomes using CBT-IA with Internet-addicted patients. Journal of Behavioral Addictions.

https://doi.org/10.1556/JBA.2.2013.4.3

\section{BIODATA PENULIS}

Henny Agustiningrum ${ }^{1}$, adalah seorang mahasiswi Magister Ilmu Komunikasi program pascasarjana di Sekolah Tinggi Ilmu Komunikasi (STIKOM) InterStudi.

Martani Huseini ${ }^{2}$, adalah seorang guru besar di Departemen Ilmu Administrasi, Universitas Indonesia.

Kinkin Yuliaty Putri Subarsa ${ }^{3}$, adalah seorang dosen tetap di Universitas Negeri Jakarta dengan latar belakang pendidikan S3 bidang ilmu komunikasi. Saat ini juga berprofesi sebagai Wakil Dekan I Bidang Akademik Fakultas Ilmu Sosial UNJ 